Dhaka Univ. J. Biol. Sci. 19(1): 63-72, 2010 (January)

\title{
EFFECTS OF DEFORESTATION ON THE PROPERTIES OF SOIL OF SAL FORESTS IN BANGLADESH
}

\author{
Mohammad Zabed Hossain*, Mihir Lal Saha, Chaman Binta Aziz \\ AND SIRAJUl HOQUE ${ }^{1}$ \\ Department of Botany, University of Dhaka, Dhaka-1000, Bangladesh
}

Key words: Bacterial colony, Deforestation effects, Sal forest, Soil physico-chemical properties

\begin{abstract}
This study examined the effect of deforestation on the soil properties (physico-chemical and bacterial) of the Sal (Shorea robusta Roxb. Ex Gaertn.) forests in Bangladesh. Physico-chemical properties and the bacterial colony counts of soil were studied by comparing a natural Sal forest site with deforested and planted with Menjium site, deforested and planted with Mahogoni site, as well as deforested but not planted but covered with profuse growth of Axonopus compressus grass species site. Moisture content was significantly lower in the deforested and planted with Menjium site and deforested and planted with Mahogoni site than the natural forest site and the deforested but not planted site. Total organic carbon, total nitrogen and available nitrogen contents were significantly lower in the natural forest site. Significantly higher number of bacterial colony and higher organic carbon and moisture contents were found in the deforested but not planted site indicating that both organic carbon and moisture content were important for microbial growth. The present study clearly showed that deforestation significantly altered the soil physico-chemical and bacterial communities of the $\mathrm{Sal}$ forests. It was also revealed that plantation with different exotic plants were found to be different in influencing soil properties.
\end{abstract}

\section{Introduction}

Effects of deforestation on the properties of soil are manifold. Changes in the soil physico-chemical properties due to deforestation are associated with a number of changes in the soil hydrological regime, microclimate, and energy balance of the forest ecosystems.(1) Alteration in the soil microbial communities as a result of deforestation is likely to influence ecosystem properties since they play the key role in organic matter decomposition and nutrient mineralization in the terrestrial ecosystems. ${ }^{(2)}$ Therefore, it is important to understand the effects of deforestation on the properties of soil particularly in the tropics like Bangladesh where the rate of deforestation is alarming due to population pressure and rapid urbanization.

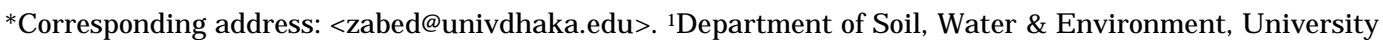
of Dhaka, Dhaka-1000, Bangladesh. 
The Sal forests dominated by Sal (Shorea robusta Roxb. Ex Gaertn.) in the central plains and north-western regions of Bangladesh is mostly a deciduous forests. ${ }^{(3)}$ Having a total area of $1,20,000$ hectares in the country the Sal forests support livelihood of a significant number of people living surrounding the area.(4) However, with an alarming average annual deforestation rate of $3.3 \%$ in the country, the $S a l$ forests along with other forest areas have been disappearing fast.(5) Clear cutting, encroachment, and indiscriminant plantation are some of the key causes of deforestation in the Sal forests in Bangladesh. Although some data are available on the effects of deforestation on the soil properties of the tropical Sal forests in Indian part, there is a dearth of data on it in the Sal forests areas of Bangladesh. ${ }^{(1,6)}$ Therefore, the aim of the present study was to find out the effect of deforestation on soil properties through a comparative analysis of soil physico-chemical and bacteriological characteristics of a natural forests and deforested sites under Sal forests area.

\section{Materials and Methods}

Site description: The Sal forests in Bangladesh are mostly deciduous in type and distributed mostly in the central plains of Madhupur tract under Gazupir, Mymensingh and Tangail districts and the north-western district of Dinajpur of Bangladesh. ${ }^{(3,4)}$ The $S a l$ forests in the Madhupur tract is moist deciduous while that in the Dinajpur district is dry deciduous in type. The $S a l$ forest of the Madhupur tract was selected for this study. Sal forests consist of both highlands called 'Chalas' covered by forest plants predominantly $\mathrm{Sal}$ and depressions called 'Baids' are cultivated with rice. The annual rainfall of the area is $c a .1800 \mathrm{~mm}, 90 \%$ of which occurs in the period of May through October.(7) The temperature of the area is moderate ranging from 30.3 to $20.9^{\circ} \mathrm{C}$. ${ }^{(8)}$

Deforestation in the Madhupur Sal forest was done mostly for cultivation of pineapple and banana about 40 to 50 years ago. In 1989, with a view to afforestation, the Government of Bangladesh handed over forest areas to Eucalyptus (Eucalyptus sp.), Menjium (Acacia menjium), and Mahogoni (Swietenia mahagoni) plantations under a program entitled "Thana Afforestation and Nursery Development Project" funded by the Asian Development Bank. In this study, three deforested sites in addition to a natural Sal forest site, were selected that included deforested and planted with Menjium site, deforested and planted with Mahogoni site and deforested but not planted with tree species site. The last one was found to be covered with profuse growth of grass species mostly Axonopus compressus.

All of the four study sites were selected within approximately two kilometers from each other in the Sal forest under Gazipur district with a view to minimizing variation in soil properties due to geographical distance and climate (Fig.1). The 

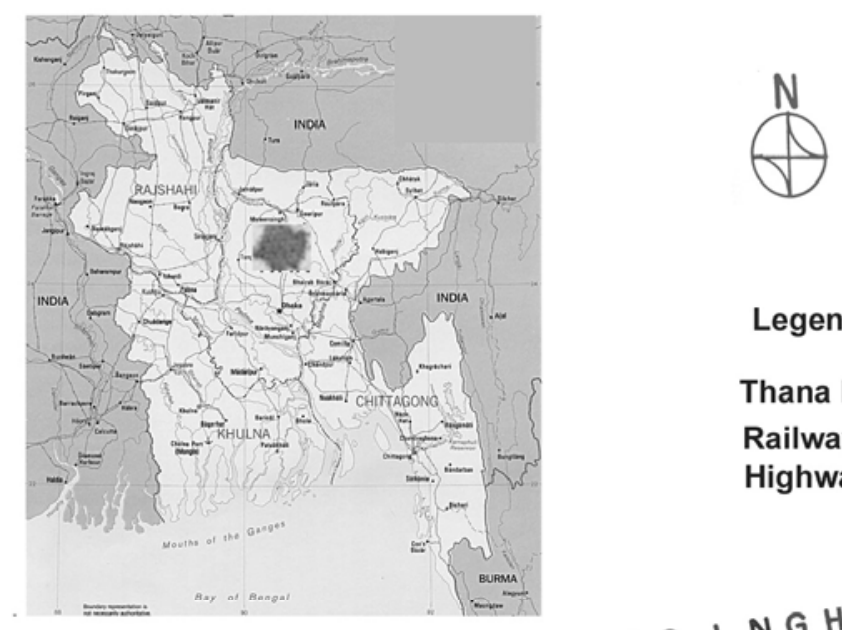

\section{Legend}

Thana boundary......

Railway

Highway

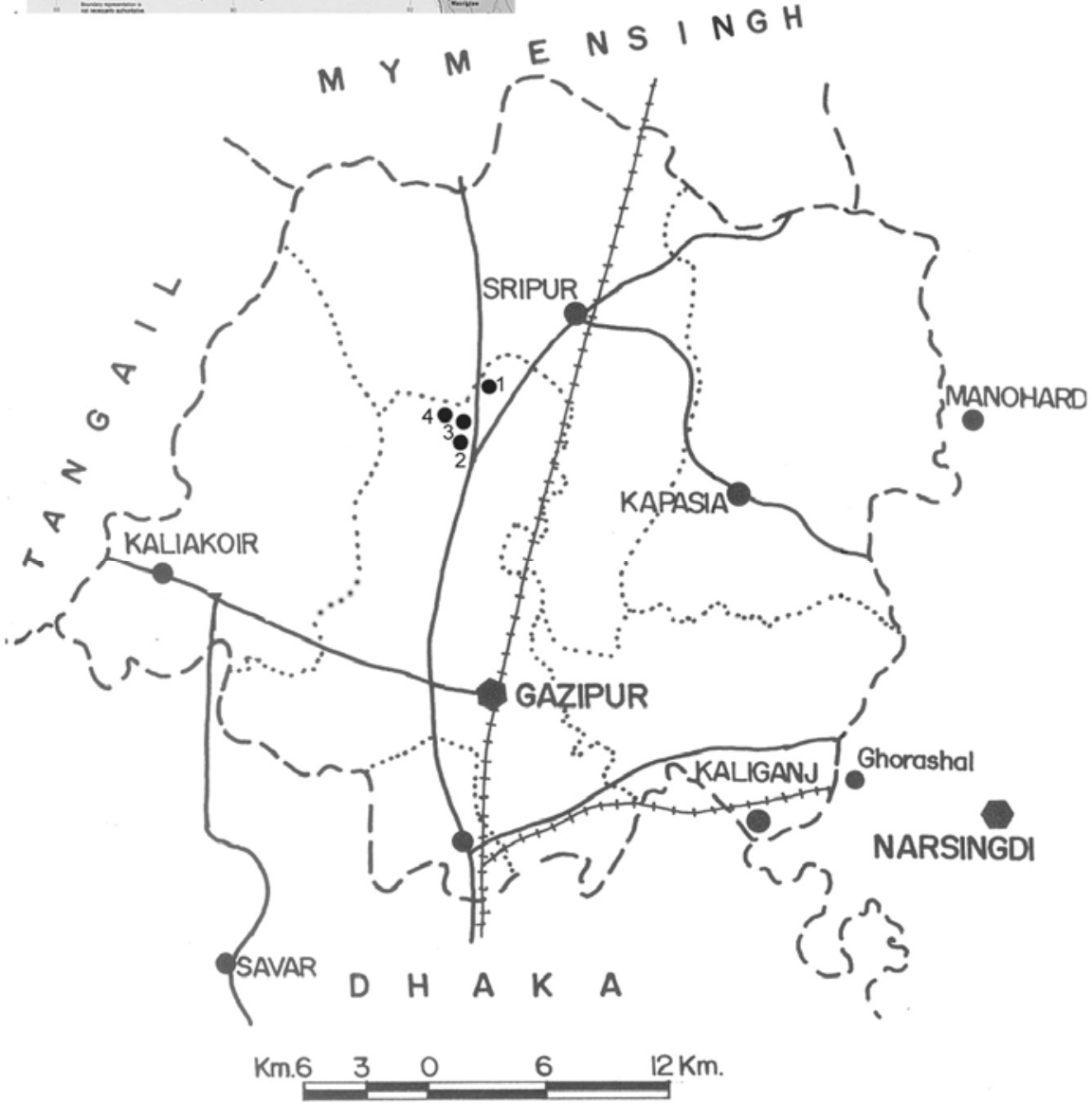

Fig. 1. Map showing the study sites selected from the $S a l$ forests area under Gazipur district, Bangladesh. The numbers 1, 2, 3 and 4 stand for the sites of natural Sal forest, deforested and planted with Menjium, deforested but not planted, and deforested and planted with Mahogoni, respectively. 
natural Sal forest site was selected at north to the Bhawal National Park in the eastern side of the Dhaka-Mymenshingh road. The deforested and planted with Menjium site was about $2 \mathrm{~km}$ south of the natural forest site in the west site of the Dhaka-Mymenshingh road in the Salna area. The deforested but not planted with tree site was about $500 \mathrm{~m}$ north to the deforested and planted with Menjium site in the North Salna. The deforested and planted with Mahogoni site was also in north Salna which was about $500 \mathrm{~m}$ north-west to the deforested but not planted site.

Vegetation analysis and soil sampling: Vegetation analysis and soil sampling were done in September, 2008. A $100 \mathrm{~m}$ long transect was placed in each of the four study sites, namely natural forest site, deforested and planted with Menjium site, deforested and planted with Mahogoni site and deforested but not planted site. Then, a quadrat of $64 \mathrm{~m}^{2}(8 \times 8 \mathrm{~m})$ was placed at a distance of $50 \mathrm{~m}$ from each other along the transect so that a total of three quadrats were placed in each site. Although a single type of quadrat $\left(64 \mathrm{~m}^{2}\right)$ was placed in the natural forest site, another type of quadrat of $0.25 \mathrm{~m}^{2}(0.5 \times 0.5 \mathrm{~m})$ in size was placed in the centre of the $64 \mathrm{~m}^{2}$ quadrat in the other three deforested sites since plants growing naturally in these sites were herbaceous in habit. Then, vegetation analysis was done in $64 \mathrm{~m}^{2}$ quadrat in the natural forest site and in $0.25 \mathrm{~m}^{2}$ quadrates in the three deforested sites. In the deforested sites, planted tree species were also counted in the $64 \mathrm{~m}^{2}$ quadrat. Soil sample was taken from the centre of each of the quadrats. Plants were identified by visual observation and by comparing with herbarium specimens of the Salar Khan Herbarium, Department of Botany, University of Dhaka.

Soil samples were collected from $0-10 \mathrm{~cm}$ depth and kept in a plastic bag. Immediately after collection, soil samples were brought to the laboratory and separated into two sub-samples; one for bacteriological analysis that was kept in a refrigerator at $4^{\circ} \mathrm{C}$ and the other for the analysis of physico-chemical properties. The collected soils were sieved through a 2-mm-mesh screen to remove plant roots, rocks, and macrofauna. After sieving, soil samples were analyzed to characterize their physico-chemical properties.

Analysis of soil physico-chemical properties: The $\mathrm{pH}$ of soil was measured in a soil water suspension ( $1: 2$, soil : water). Soil moisture content was determined by weight loss after drying $10 \mathrm{~g}$ fresh soil at $60^{\circ} \mathrm{C}$ for $24 \mathrm{~h}$. Total $\mathrm{N}$ was determined by Kjeldahl method following extraction from $2 \mathrm{~g}$ soil with conc. $\mathrm{H}_{2} \mathrm{SO}_{4} .^{\left({ }^{9}\right)}$ Available $\mathrm{N}$ content was also determined by Kjeldahl method following extraction from $10 \mathrm{~g}$ dry soil using $1 \mathrm{~N} \mathrm{KCl}$ solution. Organic carbon content of the soil was determined by Wakley and Black method using $1 \mathrm{~g}$ soil.(9) Organic matter was determined by multiplying the value of organic carbon by 1.724 (Van Bemmelen factor).

Bacteriological analysis: Nutrient agar medium was used for the enumeration of bacteria present in soil samples. The $\mathrm{pH}$ was adjusted before the addition of agar and 
sterilization. Serial dilution plate technique was used for the isolation of bacteria. ${ }^{(10)}$ One gram soil sample was diluted $(1: 100)$ with $100 \mathrm{ml}$ distilled water in a sterile conical flask and shaken well. This suspension was then used to prepare serial dilutions. One $\mathrm{ml}$ of this suspension was transferred to $9 \mathrm{ml}$ of sterile water for tenfold $(1: 10)$ dilution and further diluted up to $10^{5}$ times dilutions.

Plating in duplicate plates was made for each diluted sample. One $\mathrm{ml}$ of each of the diluted sample was taken in a sterilized Petri dish by pipette. Then molten agar medium was poured and mixed thoroughly by rotating the Petri dish, first in one direction and then in the opposite direction. After setting the medium, the plates were inverted and incubated at $37^{\circ} \mathrm{C}$ for $48 \mathrm{~h}$ in an incubator (Memmert $\mathrm{GmbH}+\mathrm{Co}$ Kg 8540 Schwabach).

After $48 \mathrm{~h}$ of incubation, the plates having well discrete colonies were selected for counting. The selected plates were placed on a colony counter (Digital colony counter, DC-8OSK 1000086, Kayagaki, Japan). Colonies were counted and categorized into three groups based on different sizes such as large, intermediate and small colony.

\section{Results and Discussion}

Vegetation structure: In the natural Sal forest site, the average number of species in a quadrat $\left(64 / \mathrm{m}^{2}\right)$ was 9.6 (Table 1 ). The species richness excluding the planted species, in deforested and planted with Menjium site, deforested and planted with Mahogoni site and deforested but not planted site in a quadrat $\left(0.25 / \mathrm{m}^{2}\right)$ were 2.0 , 2.33 , and 1.67, respectively. Plant density in the natural forest site in a quadrat (64 $\mathrm{m}^{2}$ ) was 126.67. Among the deforested sites mean plant density, excluding planted trees, in a quadrat $\left(0.25 \mathrm{~m}^{2}\right)$ was the highest in the deforested but not planted site (134.33) followed by deforested and planted with Menjium site (53) and deforested and planted with Mahogoni site (25.67). The average number of planted trees in the deforested sites was 22 per $64 \mathrm{~m}^{2}$. In the natural forest site, the highest coverage in a quadrat $\left(64 \mathrm{~m}^{2}\right)$ was for $S$. robusta $(31.35 \%)$ followed by Curcuma zeoderia (23.50\%). A. compressus showed the highest coverage in a quadrat $\left(0.25 \mathrm{~m}^{2}\right)$ in all of the three deforested sites; $88.79 \%$ in deforested and planted with Menjium site, $84.42 \%$ in the deforested and planted with Mahogoni site and 97.91\% in the deforested but not planted site. The average undergrowth vegetation height in the natural sites was $97.78 \mathrm{~cm}$. Among the deforested sites, average plant height of the vegetation excluding planted tree species was $1.33,1.67$ and $2.33 \mathrm{~cm}$, respectively in deforested and planted with Menjium site, deforested and planted with Mahogoni site and deforested but not planted site.

Soil physico-chemical properties: As shown in Table 2, moisture content was significantly $(\mathrm{p}<0.005)$ higher in the natural forest site $(24.89 \%)$ and deforested but not planted site (24.70\%) than the deforested and planted with Menjium site (9.92\%) 


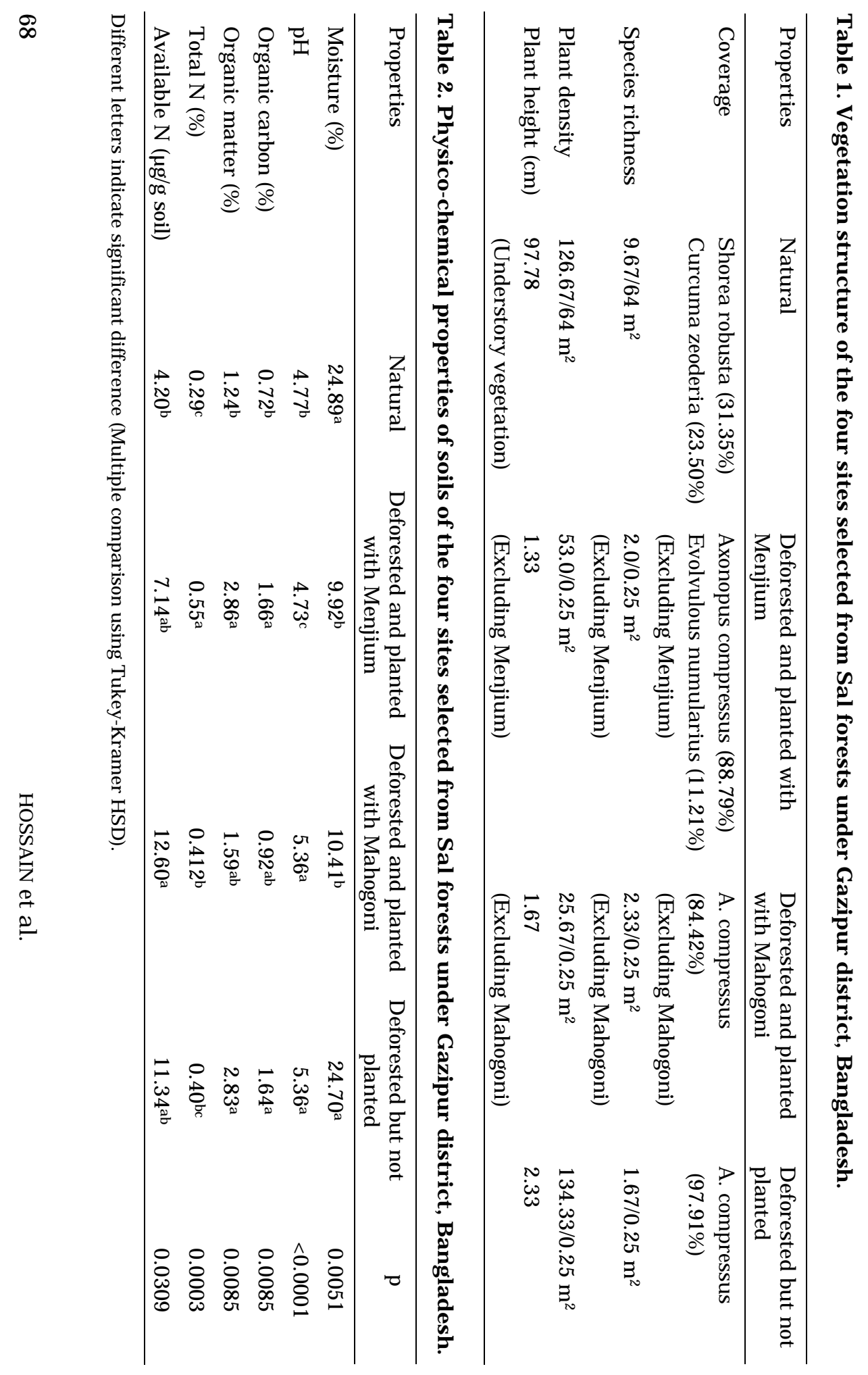


and deforested and planted with Mahogoni site (10.41\%). Soil $\mathrm{pH}$ was significantly $(\mathrm{p}<0.0001)$ higher in the deforested and planted with Mahogoni and deforested but not planted site (5.36) than deforested and planted with Mahogoni site (4.73) and the natural forest site (4.77). Percentage of organic carbon was significantly $(p<0.0085)$ higher in the deforested and planted with Menjium site (1.66) and deforested but not planted site (1.64) than the natural forest site (0.72) while deforested and planted with Mahogoni site (0.92) was intermediate. The four sites showed a trend of soil organic matter contents (\%) which was similar to that of the organic carbon contents $(\%)$. Total $\mathrm{N}$ content was significantly $(\mathrm{p}<0.0003)$ higher in the deforested and planted with Menjium site $(0.554 \%)$ and deforested and planted with Mahogoni site $(0.412 \%)$ than the other sites. Natural forest site soil also showed a significantly $(\mathrm{p}<0.03)$ lower amount of available $\mathrm{N}$ content $(4.20 \mu \mathrm{g} / \mathrm{g}$ soil) than the deforested and planted with Mahogoni site (12.6 $\mathrm{gg} / \mathrm{g}$ soil).

Soil bacterial community: Number of the total bacterial colony was significantly $(\mathrm{p}<0.0001)$ higher in the deforested but not planted site $\left(5.72 \times 10^{6} \mathrm{cfu} / \mathrm{g}\right.$ soil $)$ than the other three sites (Table 3). Similar to the total number of bacterial colony, number of bacterial colonies of various size such as large, intermediate and small were significantly higher in the deforested but not planted site than the other sites.

Table 3. Number of bacterial colony forming unit (cfu/g soil) in the four sites selected from Sal forests.

\begin{tabular}{lccccc}
\hline $\begin{array}{l}\text { Type of } \\
\text { bacterial } \\
\text { colony }\end{array}$ & Natural & $\begin{array}{c}\text { Deforested and } \\
\text { planted with } \\
\text { Menjium }\end{array}$ & $\begin{array}{c}\text { Deforested and } \\
\text { planted with } \\
\text { Mahogoni }\end{array}$ & $\begin{array}{c}\text { Deforested } \\
\text { but not } \\
\text { planted }\end{array}$ & $\mathrm{p}$ \\
\hline Large & $8.97 \times 10^{4 \mathrm{~b}}$ & $1.10 \times 10^{5 \mathrm{~b}}$ & $2.33 \times 10^{4 \mathrm{~b}}$ & $5.17 \times 10^{5 \mathrm{a}}$ & 0.0003 \\
Intermediate & $1.83 \times 10^{5 \mathrm{~b}}$ & $1.85 \times 10^{5 \mathrm{~b}}$ & $2.18 \times 10^{5 \mathrm{~b}}$ & $8.33 \times 10^{5 \mathrm{a}}$ & 0.0039 \\
Small & $4.00 \times 10^{5 \mathrm{~b}}$ & $3.32 \times 10^{5 \mathrm{~b}}$ & $3.27 \times 10^{5 \mathrm{~b}}$ & $4.73 \times 10^{6 \mathrm{a}}$ & $<0.0001$ \\
Total & $6.85 \times 10^{5 \mathrm{~b}}$ & $5.77 \times 10^{5 \mathrm{~b}}$ & $5.67 \times 10^{5 \mathrm{~b}}$ & $5.72 \times 10^{6 \mathrm{a}}$ & $<0.0001$ \\
\hline
\end{tabular}

Different letters indicate significant difference (multiple comparison using Tukey-Kramer HSD).

Plant cover decreases the evaporation rate by lowering light intensity and air movement that ultimately causes increased moisture content in soil.(11) Significantly higher moisture content in the natural forest site and the deforested but not planted site as observed in the present study might be associated with the increased plant coverage in these two sites compared to deforested and planted with Menjium site and deforested and planted with Mahogoni site. The natural forest site had stratified vegetation where $S$. robusta was the dominant tree species under which there were a number of shrub and herb species. The deforested but not planted site was densely covered with the profuse growth of $A$. compressus. Compared to the deforested and planted with Menjium site and deforested and planted with Mahogoni site density and average height of the herbaceous plants were higher in the deforested but not 
planted site indicating profuse growth of the herbaceous plants in this site. The results of the present study also indicated that Menjium and Mahogoni plants might also be responsible for the loss of water in soil, and it requires further study.

Although $\mathrm{pH}$ showed a significant difference among the four sites, soils of all of the sites studied were acidic in nature. This result was in the general agreement that Sal forest occurs mainly in acidic soil. ${ }^{(12)}$ The difference in the soil $\mathrm{pH}$ of the sites studied might be related with the changes in vegetation or other disturbances in this area.

In the present study, the organic carbon content in the natural forest site soil was found $0.72 \%$ which was almost similar to the result obtained previously by others who reported it to be $0.73 \% .{ }^{(13)}$ However, the results showed that deforestation significantly influenced the soil organic carbon content in the Sal forests. Increased organic carbon in the deforested but not planted site might be associated with the plant productivity because organic carbon (i.e. organic matter) in soil usually comes from plant sources. Deforested but not planted site showed the highest plant density (about 134 individual in a quadrat of $0.25 \mathrm{~m}^{2}$ ) compared to other two deforested sites and was densely covered with A. compressus grass species (97.91\% of all species). Other study also reported that grassland was the most productive in terms of soil organic matter production among different ecosystems. ${ }^{(14)}$ Significantly lower amount of organic carbon (i.e. organic matter), total $\mathrm{N}$ content and available $\mathrm{N}$ content in the natural forest site suggested that the natural forest was found to be less fertile and less productive compared to the deforested sites. These results agree with the general agreement that stable and mature forest sites are least fertile among other vegetation sites. ${ }^{(2)}$

Carbon content is an important determinant of the microbial growth in soil. The increased organic carbon in the deforested but not planted site might be responsible for the increased bacterial abundance in this site. Other study also showed that microbial biomass is positively related to soil organic matter contents in most ecosystems. ${ }^{(15,16)}$ However, in addition to carbon availability in soil, moisture content is also an important factor for microbial growth. ${ }^{(17)}$ Therefore, in spite of increased organic carbon due to lower moisture content in soil, soil bacterial biomass was significantly lower in the deforested and planted with Menjium site than deforested but not planted site where both organic carbon and moisture contents were significantly higher. These results thus indicate that availability of both carbon and moisture content is important for the microbial growth in soil.

Results of the present study also showed that the deforested sites did not support any undergrowth vegetation as like as in the natural $\mathrm{Sal}$ forests site although the deforested sites were planted by $A$. menjium and $S$. mahagoni about 20 years ago. These results thus suggest that development of undergrowth vegetation in Sal 
forests has ecological association with $S$. robusta. It was also suggested that the microclimatic differences in temperature, light and air due to canopy occupied by $S$. robusta has influence on the growth and establishment of undergrowth vegetation. ${ }^{(18)}$ The results also suggest that clear cutting of $S$. robusta will consequently cause loss of plant diversity in this typical forest. Changes in vegetation structure due to deforestation have also been reported by some workers. ${ }^{(19)}$

Overall, the results of the present study showed that deforestation significantly altered the physico-chemical and microbial properties of the soil of Sal forests. Data also showed that plantation by different exotics might also have significant influence on soil properties. The results of this study thus suggest that the changes in soil properties due to deforestation and plantation by exotics should be taken into consideration while attempts are made for the management of the Sal forests.

\section{References}

1. Sahani U and N Behera 2001. Impact of deforestation on soil physico-chemical characteristics, microbial biomass and microbial activity of tropical soil. Land Degradation \& Development 12: 93-105.

2. Wardle DA 2002. Communities and ecosystems: Linking the aboveground and belowground components Princeton University Press.

3. Khan MS 1991. The vegetation of Bangladesh. In: Plant life of South Asia (Ali SI and A Gaffar Eds). pp. 185-192.

4. Alam MK 2008. Forests and forestry in Bangladesh. In: Encyclopedia of flora and fauna of Bangladesh. Vol. 1. Bangladesh Profile. Asiatic Society of Bangladesh. pp. 73-86.

5. Khan NA, JK Choudhury, KS Huda and MI Mondal 2004. An overview of social forestry in Bangladesh. Forestry Sector Project, Bangladesh Forest Department. pp. 198.

6. Srivastava SC and JS Singh 1989. Effects of cultivation on microbial biomass C and N of dry tropical forest soil. Biology and Fertility of Soils 8: 343-348.

7. Manalo EB 1976. Agro-climatic survey of Bangladesh. BRRI/IRRI. Los Banos, Leguna, Philippines.

8. Ghani CQ, A Alim and PR Stevens 1990. Rehabilitation and land use planning of Sal forests, parts I, II, and III. FAO/UNDP Project 85/085, Assistance to the forestry sector, Phase II, Dhaka, FAO.

9. Black CA 1965. Methods of soil and plant analysis. Part I and II. American Society of Agronomy.

10. Greenberg AE, JJ Connors, D Jekins and MAH Franson 1998. Standard methods for examination of water and wastewater. $20^{\text {th }}$ edn. APHA, Washington DC.

11. Bannister P 1980. Introduction to physiological plant ecology. Blackwell Scientific Publications.

12. Mooney HF 1947. A note on southern unit of 'Sal' (Shorea robusta) in Orissa and Bihar State. Indian Ecologist 1: 27-31.

13. Ismail M and MMK Mia 1973. Studies on some deciduous Sal forest of Bangladesh. 
14. Schlesinger WH 1997. Biogeochemistry: an Analysis of Global Change. Academic Press, San Diego, CA, USA.

15. Zak DR, D Tilman, RR Parmenter, CW Rice, FM Fisher, J Vose, D Milchunas and CW Martin 1994. Plant production and soil microorganisms in late-successional ecosystems: A continental-scale study. Ecology 75: 2333-2347.

16. Baer SG, JM Blair, S Collins and AK Knapp 2003. Soil resources regulate productivity and diversity in newly established tallgrass prairie. Ecology 84: 724-735.

17. Steinberger Y, L Zelles, QY Bai, M von Lutzow and JC Munch 1999. Phospholipid fatty acid profiles as indicators for the microbial community structure in soils along a climatic transect in the Judean desert. Biology and Fertility of Soils 28: 292-300.

18. Jones GH. 1983. Plants and microclimate. Cambridge University Press.

19. Mehta VK, PJ Sullivan, MT Walter, J Krishnaswamy, SD DeGloria 2008. Ecosystem impacts of disturbance in a dry tropical forest in southern India. Ecohydrology 1: 149-160.

(Manuscript received on 1 July, 2009; revised on 15 July, 2009) 